\title{
ENVIRONMENTAL CARRYING CAPACITY BASED ON LAND BALANCE FOR EVALUATION PLANNING OF SPATIAL AND REGIONAL IN SOLOK REGENCY, WEST SUMATRA
}

\author{
Alvan Pahuluan ${ }^{1,2}$, Tri Retnaningsih Soeprobowati ${ }^{1,3}$, Hady Hadiyanto ${ }^{1,4, *}$ \\ 1 Master Program of Environmental Science, School of Postgraduate Studies, Diponegoro University, Semarang \\ 50421 , Indonesia \\ 2 Environmental Management Office of Solok Regency Government, Arosuka 27365, Indonesia \\ 3 Department of Biology, Faculty of Sains and Mathematics, Diponegoro University, Semarang 50421, Indonesia \\ ${ }^{4}$ Department of Chemical Enginering, Faculty of Enginering, Diponegoro University, Semarang \\ 50421 , Indonesia \\ * Corresponding author's e-mail: hadiyanto@live.undip.ac.id
}

Received: 2017.02.14

Accepted: 2017.03.07

Published: 2017.05 .02

\begin{abstract}
Act No. 26 of 2007 on Spatial Planning stated that the central and the local government should establish Spatial and Regional Planning (RTRW) by considering environmental carrying capacity. The environmental carrying capacity based RTRW will ensure the balance between the use of natural resources and the prevention of negative impacts on the environment. The objective of this study was to evaluate the implementation of RTRW at Solok Regency Year 2012-2031 which has been established in 2013. Evaluation was conducted by calculating land carrying capacity method to determine land supply and land demand. The results showed that the land use planned as stated in the RTRW increase the land supply in supporting bio-product production to meet the needs of the population, with surplus conditions amounted to $101,005.79$ hectares. The future predictions indicated that the carrying capacity of planned land could met the needs of the population bio-product until the year 2121. The evaluation of the spatial pattern plan showed that there was a need to increase the area of housing and settlements in accordance with the rate of population increase and determine the extents area for the development of the livestock sector to improve its yield.
\end{abstract}

Keywords: spatial planning, land carrying capacity, land supply, land demand, Solok Regency

\section{INTRODUCTION}

The development is an effort to meet human needs to be better, or in other words, to increase the level of life and human well-being. These needs require ability of the environment to support life at a higher level to avoid damaged of environment. The development was not only beneficial for humans but it also has a risk to the environment. Therefore, the development activities must take into account the risks-benefits to the environment (Soemarwoto, 2004).
On another hand, population growth resulted in an increased number of needs and increasing economic activities (Cukur, 2014; Kusumandari and Nugroho, 2015). These have an impact on consumption of natural resources and environmental quality owned (George and Kini, 2016; Hui, 2015). To overcome these problems, an assessment of the environmental carrying capacity in utilization of land is required (Abdelrahman et al., 2016).

Environmental carrying capacity is a measure of the environmental ability to support hu- 
man's life, other living beings, and the balance between both of them and a measure of the environmental ability to absorb energy and / or other sincorporated components (Rees and Wackernagel, 1996). Environmental carrying capacity is an indicator of the sustainable development implementation in the specific area. Environmental carrying capacity is also defined as a comparison between the environmental pressure (demands on natural resources) against the threshold the environment (availability of natural resources) (Liu dan Borthwick, 2011).

In realizing the balanced development inter regions in the use of natural resources and the prevention of negative impacts on the environment, spatial planning is required. Development planning through spatial planning serves to support sustainable environment management, no wastage of space utilization and not cause deterioration in the quality of space. To achieve these criteria, developments planning have to consider the environmental carrying capacity (Oh et al., 2005).

Environmental capacity needs to ensure the development activities undertaken which are still at the lower limit of the environmental standards (Lee and Oh, 2012), so that the development activities are environmentally friendly and sustainable resource utilization for the future (Lane, 2010; Wei et al., 2015; George and Kini, 2016).

This concept has been used by Government of the Republic of Indonesia contained in the Act (UU) 26 of 2007 on Spatial Planning, wherein chapters 19, 22 and 25 stipulated that the government and regional governments must compose Regional and Spatial Plan (RTRW) with due regard to environmental carrying capacity. Implementation of this rule is also described in Regulation of the Minister of Environment (PermenLH) No 17 Year 2009 about the Guidelines for Determining Environmental Carrying Capacity In Regional Spatial Planning. These guidelines are not only used to determine the environmental carrying capacity of the area but are also used to evaluate the utilization of space.

Spatial planning is the arrangement of settlement centers and network infrastructure that support the social economy and the public distribution of utilization space in an area including the spatial allocation of protection functions and cultivation function. While the RTRW is a result of spatial planning that contains objectives, policies, and strategies for spatial planning, from planning, use, and control of the utilization of space (Act 26/2007).
Spatial planning aims to mitigate environmental impacts caused by development activities (Hegazy, 2015), avoiding development activities are not planned that can also have negative impacts on the environment (Gerundo and Grimandi, 2011) and maintain land use made of the decline the quality of land (Shi et al., 2010). Spatial planning should also be able to maintain a balance between all the economic, social and environmental interests (Fuseini and Kemp, 2015), free from political pressures and private interests (Goncalves and Ferreira, 2015).

Solok regency is one of the regencies in West Sumatra Province that set RTRW through Regional Regulation (Perda) No. 1 of 2013 on Spatial Planning Solok regency in 2012-2031. However, implementations of RTRW are not fully in agreement with the existing provisions of PermenLH 17/2009, which consider carrying capacity of land by comparing between supply and demand of land. Based on these problems, the purpose of this study was to evaluate the RTRW Solok Regency Year 2012-2031 in terms of carrying capacity of the owned land (existing) and predefined land allocation (RTRW) as well as to give recommendations on improvements of RTRW.

\section{EXPERIMENTAL SECTION}

\section{Location}

Solok Regency is located in the province of West Sumatra, Republic of Indonesia. Geographically, this region lies on coordinates $00^{\circ} 32^{\prime} 14^{\prime \prime}$ $01^{\circ} 46^{\prime} 45^{\prime \prime}$ southern latitude and $100^{\circ} 25^{\prime} 00^{\prime \prime}-101^{\circ}$ $41^{\prime} 41 "$ eastern longitude. The area of Solok regency is 373,800 hectares that consists of 14 sub-districts and 74 villages. The landscape is varied, the highlands in the south to centre and the lowlands in the north, with a height ranging from 284 to 1458 meters above the sea level. The area is a tropical climate with temperature range $18-30{ }^{\circ} \mathrm{C}$ and an average rainfall of $2,054 \mathrm{~mm}$ per year.

\section{Method of Research}

Data needed and available data sources for this study are presented in Table 1. The calculation is done based on the methods set out in PermenLH No. 17/2009. Several stages of analysis to be performed are:

1. Calculation of the carrying capacity of the land (Existing) 
Table 1. Type and source of data research

\begin{tabular}{|c|c|}
\hline Type of Data & Data Source \\
\hline $\begin{array}{l}\text { Production of rice, } \\
\text { agricultural non-rice, } \\
\text { plantation, forestry, livestock } \\
\text { and fishery }\end{array}$ & $\begin{array}{l}\text { Statistics Agency Solok } \\
\text { Regency } \\
\text { Department of Agriculture } \\
\text { Solok Regency } \\
\text { Department of Husbandry } \\
\text { And Fisheries Solok } \\
\text { Regency } \\
\text { Department of Forestry And } \\
\text { Plantation Solok Regency }\end{array}$ \\
\hline $\begin{array}{l}\text { Price of rice } \\
\text { Prices of commodity non- } \\
\text { rice }\end{array}$ & $\begin{array}{l}\text { Statistics Agency Solok } \\
\text { Regency } \\
\text { Survey of prices in level } \\
\text { producer }\end{array}$ \\
\hline Total population & $\begin{array}{l}\text { Statistics Agency Solok } \\
\text { District }\end{array}$ \\
\hline
\end{tabular}

Determining the land carrying capacity is done by calculating land supply and land demand. The land supply is calculated using the equation:

$$
\mathrm{SL}=\frac{\sum\left(\mathrm{P}_{\mathrm{i}} \times \mathrm{H}_{\mathrm{i}}\right)}{\mathrm{H}_{\mathrm{b}}} \times \frac{1}{\mathrm{Ptv}_{\mathrm{b}}}
$$

where: $S L$ : The land supply $(\mathrm{Ha})$

$\mathrm{Pi}$ : Actual production of commodity (unit depending on the type of commodity).

$\mathrm{Hi}$ : The Unit price of commodity (IDR / unit) at the manufacturer

$H b$ : Rice Unit price (IDR / $\mathrm{kg}$ ) at the producer level

Ptvb : Rice Productivity (Kg / $\mathrm{Ha})$

While for the land demand is calculated using the equation:

$$
D_{L}=N \times K H L_{L}
$$

where: $D_{L}:$ The total land demand of rice equivalent (Ha)

$N$ : Total population (person)

$K H L_{L}$ : The land area needed for decent living needs per population (Ha/person)

Area of land required for a decent life needs per population is the need for decent living population divided productivity of local rice. The need for decent living per population is assumed to equal 1 ton of rice/capita/year.

Determination status of land carrying capacity is determined by calculating the ratio between supply and demand of land, to determine the condition of the region in a status of surplus or deficit. Value ratio translated based on the criteria on the status of environmental capacity in Table 2.

The Status of surplus occurs when the land supply can still be sufficient for biological production in the region (SL> DL), while the status of deficit occurs when the land supply is not able to meet the production needs of biodiversity in the region (SL $<$ DL) (Table 2).

\section{Calculation of Land Rent value}

First, the land rent value is obtained by translating the production value of commodity to the land-use area for producing the commodity. Then the land rent value calculated with equation:

$$
\text { Land rent }=\frac{\text { Total production commodities }}{\text { Land area }}
$$

3. Calculation of the carrying capacity of land RTRW

Before calculating the carrying capacity of land RTRW, determine the value of the land production RTRW by translating the land rent value of the existing land to the planned land of RTRW. The land production value of RTRW is calculated by multiplying the land rent value per hectare of existing land with the planned land area of RTRW.

These land production values used to determine the land supply of RTRW (use equation 1) and for determining the land demand of RTRW using a total population that has been projected in the same year (use equation 2).

4. RTRW evaluation using land carrying capacity

The evaluation was done based on the land supply and the land demand owned by RTRW scenarios. Recommendations from the evaluation will be given for the achievement of the management of land resources optimally in Solok Regency in the future according to the plan contained in the RTRW.

\section{RESULTS}

\section{Land carrying capacity (existing)}

The First step in determining the land supply is identifying the commodities produced in Solok Regency (data 2014), with the results:

a. Agricultural commodities consist of the production of rice, secondary crops, fruits, vegetables, and medicinal plants.

Table 2. Criteria for Determining Status of Environmental Carrying Capacity

\begin{tabular}{|c|c|}
\hline $\begin{array}{c}\text { Value Ratio of Supply/ } \\
\text { Demand }\end{array}$ & Status \\
\hline$>2$ & Sustain \\
\hline $1-2$ & Conditional sustain \\
\hline$<1$ & Overshoot \\
\hline
\end{tabular}


b. Livestock commodities consist of meat and egg production.

c. Fisheries commodities, the total catch of fish farmed and public waters.

d. Plantation crops commodities.

Actual production value of commodities is calculated by multiplying the number of commodity production with a commodity unit price, the results shown in Table 3.

Knowing the current production value of commodities (see Table 3), we can calculate the land supply using equation 1 and the land demand by using equation 2 . Local rice productivity is calculated by comparing the total amount of rice production value with a total of rice harvest area and the value of the land area for a decent living is calculated by comparing decent living needs per population (assumed to equal 1 ton of rice/capita/ year) with local rice productivity. Calculation results can be seen in Table 4.

Table 3. Production value of commodities in 2014

\begin{tabular}{|c|c|}
\hline Commodities & $\begin{array}{l}\text { Production value } \\
\text { (in Billion IDR) }\end{array}$ \\
\hline Rice and secondary crops & $2,186.04$ \\
\hline Fruits & 900.16 \\
\hline Vegetables & $1,949.49$ \\
\hline Medicinal plants & 26.81 \\
\hline Meat production & 67.81 \\
\hline Egg production & 27.84 \\
\hline Fish & 41.85 \\
\hline Plantation crops & 144.51 \\
\hline TOTAL & $5,344.51$ \\
\hline
\end{tabular}

From Table 4, it is known that the status of land carrying capacity in 2014 is Conditionally Sustained. Land conditions have a surplus, where land supply is greater than land demand (SL> DL), which means that the land supply in Solok Regency is still insufficient for biological production needs for the entire population of the region.

\section{Land rent value of the Existing Land}

Land rent value is obtained by translating commodity production values (Table 2 ) into the existing land use in accordance with the source of its commodity production. Land rent value per hectare is calculated by dividing the total production value of the commodity with production land area. The results of this value can be seen in Table 5.

In Table 5, a commodity can be generated in more than one type of land use. For example, meat production relates to agricultural land and pasture. The assessment proportion of land use is calculated by assuming that which more dominant land generated from land use. Land use of pasture is more dominant than the agriculture, then the production value for pasture and agriculture respectively by $75 \%$ and $25 \%$ of the total production value of these commodities.

\section{Land Capability Based on RTRW}

Like the carrying capacity of existing land, land carrying capacity based RTRW is also calculated by determining land supply and land demand by using equation (1) and (2). Before

Table 4. The Calculation of the Land Carrying Capacity in 2014

\begin{tabular}{|c|c|c|c|}
\hline Factor & Formula & Value & Unit \\
\hline \multicolumn{4}{|c|}{ THE LAND SUPPLY } \\
\hline Production value of commodity & $\Sigma(\mathrm{Pi} \times \mathrm{Hi})$ & $5,344.51$ & Billion IDR \\
\hline Rice Unit price & $\mathrm{Hb}$ & $10,046.00$ & IDR/Kg \\
\hline Local rice Productivity & Ptvb & $3,449.10$ & $\mathrm{Kg} / \mathrm{Ha}$ \\
\hline The land supply & $\mathrm{SL}=(\Sigma(\mathrm{Pi} \times \mathrm{Hi}) / \mathrm{Hb}) \times(1 / \mathrm{Ptvb})$ & $154,244.57$ & $\mathrm{Ha}$ \\
\hline \multicolumn{4}{|c|}{ THE LAND DEMAND } \\
\hline Total Population & $\mathrm{N}$ & 361,095 & Person \\
\hline $\begin{array}{l}\text { The land area needed for decent } \\
\text { living }\end{array}$ & $\mathrm{KHLL}=1$ ton $/ \mathrm{Ptvb}$ & 0.29 & $\mathrm{Ha} /$ person \\
\hline The land demand & $\mathrm{DL}=\mathrm{N} \times \mathrm{KHLL}$ & $104,717.26$ & $\mathrm{Ha}$ \\
\hline \multicolumn{4}{|c|}{ STATUS OF LAND CARRYING CAPACITY } \\
\hline The land supply & SL & $154,244.57$ & $\mathrm{Ha}$ \\
\hline The land demand & DL & $104,717.26$ & $\mathrm{Ha}$ \\
\hline Ratio & SL/DL & 1.47 & \\
\hline Status & & \multicolumn{2}{|c|}{ CONDITIONAL SUSTAIN } \\
\hline
\end{tabular}


Table 5. Calculation of the Rent Land Value of Existing Land

\begin{tabular}{|c|c|c|c|c|c|c|c|c|c|c|c|}
\hline & & & & & & XISTING LA & ND USE & & & & \\
\hline & Specification & Rice field & Field/ & Forest & Grass- & Fishpond/ & $\begin{array}{l}\text { Field } \\
\text { that }\end{array}$ & House/ & Forest & Othere & $\begin{array}{c}\text { Production } \\
\text { value }\end{array}$ \\
\hline & \begin{tabular}{|l|} 
Rice and \\
secondary \\
crops
\end{tabular} & $2,059.01$ & 127.03 & & & & & & & & $2,186.04$ \\
\hline 은 & Fruits & & 900.16 & & & & & & & & 900.16 \\
\hline 즘 & Vegetable & & $1,949.49$ & & & & & & & & $1,949.49$ \\
\hline 高 & $\begin{array}{l}\text { Medicinal } \\
\text { plants }\end{array}$ & & 26.81 & & & & & & & & 26.81 \\
\hline 考 & Meat & & 16.95 & & 50.86 & & & & & & 67.81 \\
\hline है & Egg & & 27.84 & & & & & & & & 27.84 \\
\hline O & Fish & & & & & 41.85 & & & & & 41.85 \\
\hline & $\begin{array}{l}\text { Plantation } \\
\text { crpos }\end{array}$ & & & 144.51 & & & & & & & 144.51 \\
\hline & nd area (ha) & $23,535.00$ & $38,557.00$ & $70,760.00$ & $3,505.00$ & $7,116.50$ & 32.957 & 7.028 & 145.320 & 45.021 .5 & \\
\hline & $\begin{array}{l}\text { nd rent of } \\
\text { nmodity } \\
\text { lion idr) }\end{array}$ & $2,059.01$ & $3,048.29$ & 144.51 & 50.86 & 41.85 & - & - & - & - & \\
\hline & $\begin{array}{l}\text { nd rent per } \\
\text { ctare } \\
\text { illion idr/ha) }\end{array}$ & 87.49 & 79.06 & 2.04 & 14.51 & 5.88 & - & - & - & - & \\
\hline
\end{tabular}

that, one must know the production value of the land RTRW. The production value of land RTRW calculated using the land rent value per hectare of existing land. This value is translated into the appropriate land uses in the RTRW (the same production function). Then this value is multiplied by the area allocation of land RTRW, as presented in Table 6.

From Table 6, it is known that the total value of land production of RTRW is 8,844.34 Billion Rupiahs. This value is used for calculated the prediction of the land supply of RTRW (Scenario of 2031) with an assumption that the productivity of local rice and rice prices remain unchanged. Land demand, according to land RTRW, can be predicted by total population on the same condition using the rate of population increase of $0.83 \%$ (BPS, 2010) and assuming tht decent living needs of the population do not change. The calculation result of the land carrying capacity based on RTRW land, is shown in Table 7.

Table 7 shows that the status of the land carrying capacity of RTRW (in 2031) is Sustain. It means that the land condition is surplus (SL> DL), due to the fact that land supply is greater than the land demand by the population.

Table 6. Calculation of the RTRW Land Production Value

\begin{tabular}{|c|c|c|c|c|c|c|c|c|c|c|}
\hline & \multirow[b]{2}{*}{ Specification } & \multicolumn{8}{|c|}{ Land allocation of rtrw } & \multirow{2}{*}{$\begin{array}{c}\text { Land rent } \\
\text { per hectare } \\
\text { (million idr/ } \\
\mathrm{Ha} \text { ) }\end{array}$} \\
\hline & & $\begin{array}{l}\text { Protected } \\
\text { forest }\end{array}$ & $\begin{array}{l}\text { Production } \\
\text { forest }\end{array}$ & $\begin{array}{l}\text { Farm } \\
\text { crops }\end{array}$ & $\begin{array}{l}\text { Horti- } \\
\text { culture }\end{array}$ & Plantation & Fishery & $\begin{array}{c}\text { Housing and } \\
\text { settlements }\end{array}$ & $\begin{array}{l}\text { Other } \\
\text { areas }\end{array}$ & \\
\hline \multirow{9}{*}{ 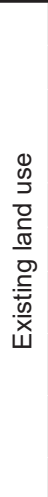 } & Rice field & & & $2,972.2$ & & & & & & 87.49 \\
\hline & Field/garden & & & & $5,729.82$ & & & & & 79.06 \\
\hline & \begin{tabular}{|l} 
Forest \\
community/ \\
Plantation
\end{tabular} & & 11.55 & & & 69.89 & & & & 2.04 \\
\hline & Grassland & & & & & & & & & 14.51 \\
\hline & Fishpond/ lake & & & & & & 60.88 & & & 5.88 \\
\hline & $\begin{array}{l}\text { Field that is not } \\
\text { cultivated }\end{array}$ & & & & & & & & & - \\
\hline & $\begin{array}{l}\text { House/ building/ } \\
\text { yard }\end{array}$ & & & & & & & $\checkmark$ & & - \\
\hline & $\begin{array}{l}\text { Forest state/ } \\
\text { protected }\end{array}$ & $\checkmark$ & $\checkmark$ & & & & & & & - \\
\hline & Others & & & & & & & & & - \\
\hline \multicolumn{2}{|c|}{ Land area (ha) } & $165,420.0$ & $28,288.00$ & $33,973.0$ & $72,475.00$ & $42,778.00$ & $10,351.45$ & $7,038.0$ & $13,476.55$ & TOTAL \\
\hline \multicolumn{2}{|c|}{$\begin{array}{l}\text { Production value } \\
\text { (billion idr) }\end{array}$} & - & 11.55 & $2,972.2$ & $5,729.82$ & 69.89 & 60.88 & - & - & $8,844.34$ \\
\hline
\end{tabular}


Table 7. The Prediction of the Land Carrying Capacity in 2031

\begin{tabular}{|c|c|c|c|}
\hline Factor & Formula & Value & Unit \\
\hline \multicolumn{4}{|c|}{ THE LAND SUPPLY } \\
\hline Production value of commodity & $\Sigma(\mathrm{Pi} \times \mathrm{Hi})$ & $8,844.34$ & Billion IDR \\
\hline Rice Unit price & $\mathrm{Hb}$ & $10,046.00$ & IDR/Kg \\
\hline Local rice Productivity & Ptvb & $3,449.10$ & $\mathrm{Kg} / \mathrm{Ha}$ \\
\hline The land supply & $\mathrm{SL}=(\Sigma(\mathrm{Pi} \times \mathrm{Hi}) / \mathrm{Hb}) \times(1 / \mathrm{Ptvb})$ & $255,250.36$ & $\mathrm{Ha}$ \\
\hline \multicolumn{4}{|c|}{ THE LAND DEMAND } \\
\hline Population in 2014 & No & 361,095 & Jiwa \\
\hline Rate of population increase & $\mathrm{r}$ & 0.83 & $\%$ \\
\hline Period & $\mathrm{t}$ & 17 & \\
\hline Population in 2031 & $\mathrm{Nt}=\mathrm{No}(1+\mathrm{r})^{\mathrm{t}}$ & 415,573 & Person \\
\hline $\begin{array}{l}\text { The land area needed for decent } \\
\text { living }\end{array}$ & $\mathrm{KHLL}=1$ ton $/ \mathrm{Ptvb}$ & 0.29 & $\mathrm{Ha} /$ person \\
\hline The land demand & $\mathrm{DL}=\mathrm{N} \times \mathrm{KHLL}$ & $120,516.22$ & $\mathrm{Ha}$ \\
\hline \multicolumn{4}{|c|}{ STATUS OF LAND CARRYING CAPACITY } \\
\hline The land supply & SL & $255,250.36$ & $\mathrm{Ha}$ \\
\hline The land demand & $\mathrm{DL}$ & $120,516.22$ & $\mathrm{Ha}$ \\
\hline Ratio & SL/DL & 2.12 & \\
\hline Status & & SUSTAIN & \\
\hline
\end{tabular}

\section{Evaluation RTRW Based on Land Carrying Capacity}

Comparison between land supply in 2014 and 2031, it is known that its increase amount to $101,005.79$ hectares (see Figure 1). This indicates an additional allocation of land for the bio-product production. From the result of the calculation, it is known that there has been an increase in the status of land carrying capacity wherein on 2014 a Conditional Sustain status into a Sustain status in 2031. Based on this, it was concluded that the land allocation plan ,which was set in the RTRW Solok Regency
Year 2012-2031, has already noticed the aspects of its land carrying capacity. It also means that the development planning has the sustainability of land resources owned in the future.

Projection on the carrying capacity of this land for several coming years was done with the assumption that the land supply is constant where cropping patterns and agricultural technology remained and land demand increases with the amount of population. The predictions show that the land carrying capacity that had been planned in the RTRW can meet the needs of the population until the year 2121. More information is provided in Figure 2.

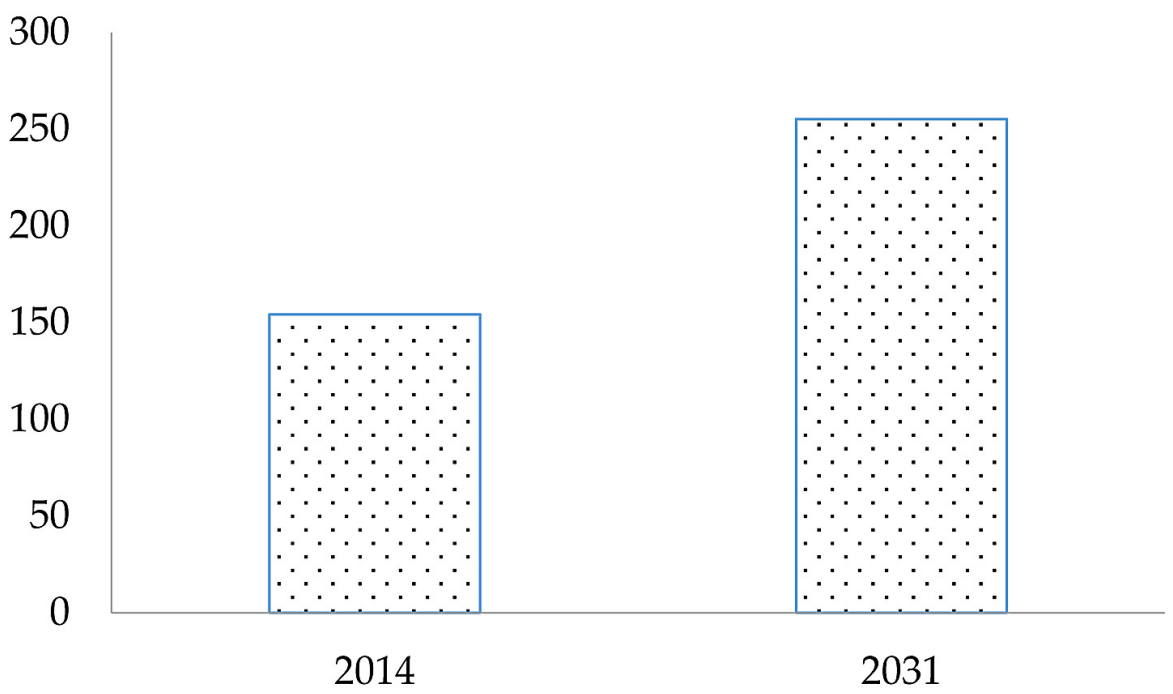

Figure 1. Comparison of land supply in 2014 and 2031 


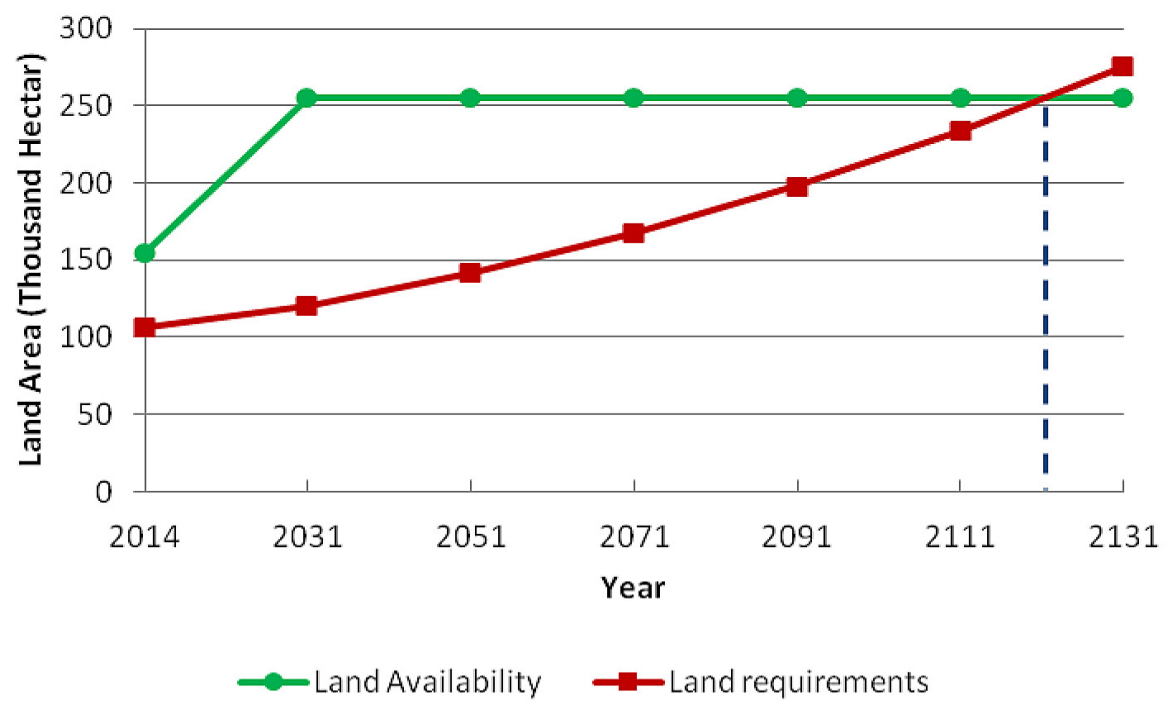

Figure 2. Projection of the Land Carrying Capacity based RTRW

\section{DISCUSSION}

The land carrying capacity of RTRW increased due to the addition of allotment of land in agriculture for food crops (rice fields) and horticulture (tegal and field) compared to the existing land use. Improved agricultural land area will increase a number of bio-product production to meet the needs of the population, so that increasing the land carrying capacity (see Figure 3 ).

Allotment of protected areas, such as protected forests and nature reserves, also has the addition of area on condition RTRW. This will have a positive influence on water supply in Solok Regency, because of the forest function as water storage. The capacity of water availability is strongly influenced by land-use planning (SerraoNeumann et al., 2016).

In contrast to agricultural and protected forest land, production forest land reduced. This is caused due to the planning land use to change convertible production forest into plantations. Interpretation of both types of land have become a bit confusing. In production, forests are also found in such types of plantation crops as rubber, nutmeg, hazelnut and other woody annual crop category. As a result, these land also can also be categorized plantations although resides on forest production.

For the fishing grounds, in figure 2 it is seen that there is the surplus of land area. It's just a difference in the categorization type of land on existing conditions with the RTRW. Allocation of fishing grounds in the RTRW improves freshwater fisheries which located on the pond, irrigation ca- nals, and the river, which is the location of the existing land included in the category of other areas.

Allocation of land for the ranch is not clearly defined. Suffice to mention that the ranch in Solok Regency directed at the whole sub-district. This causes problems in planning the livestock sector development. The livestock sector in Solok Regency still needs serious attention by the local government, because this sector is still small in contributing to the total value of a commodity production, where a commodity meat by $1.27 \%$ and eggs by $0.25 \%$. Increased livestock sector can be done by focusing development activities in the sub-district which has the potential of land resources vast grasslands, especially the sub-district IX Koto Sungai Lasi, Lembah Gumanti, Gunung Talang, X Koto Singkarak and $\mathrm{X}$ Koto Diatas that have grasslands area of more than $200 \mathrm{Ha}$ (BPS, 2015).

The allocation of housing and settlements on RTRW improved 10 hectares or $0.14 \%$ from 2014 but not relevant if you take into account the rate of population increase and the rate of change of land for settlements that occurred in the last 5 years, which amounted to 417 hectares (BPS, 2015).

A constraint of this study is a limitation of the data that belongs to calculate the land production value. Forestry commodity data is not available so that calculations do not represent the whole area studied. This affects to the calculation of the value of farm production in the RTRW (see Table 6) wherein the category of protected forest land only by a tick $(\checkmark)$ because its value cannot be calculated because of inaccessibility. 


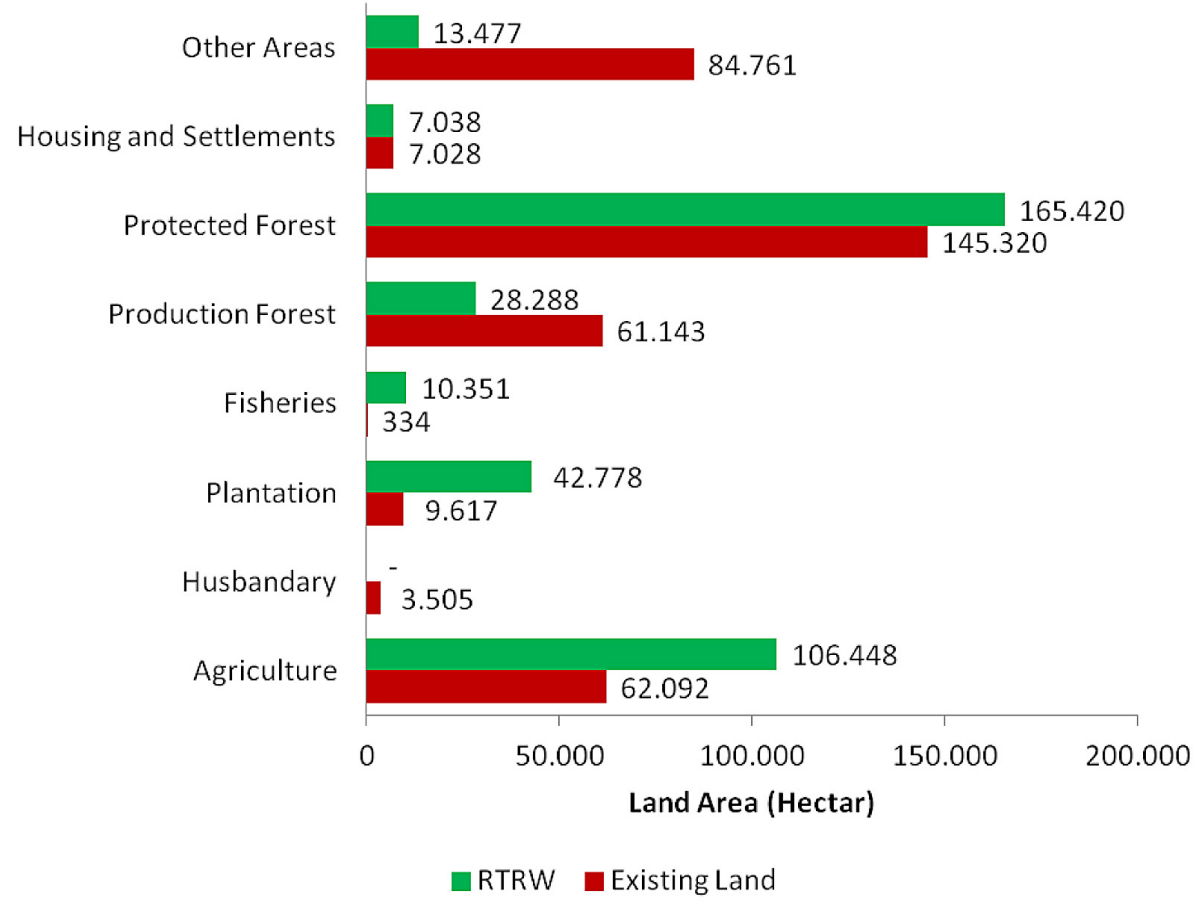

Figure 3. Comparison of Existing Land-use and Allocation in RTRW

\section{Acknowledgments}

Thanks to Pusbindiklatren BAPPENAS R.I. which has provided scholarships to continue my education at the Master Program of Environmental Science Graduate School of Diponegoro University, Semarang and Local Government of Solok Regency, West Sumatra Province which has given agreement of the task of studying in Diponegoro University.

\section{REFERENCES}

1. AbdelRahman, M.A.E., Natarajan, A. and Hegde R. 2016. Assessment of land suitability and capability by integrating remote sensing and GIS for agriculture in Chamarajanagar district, Karnataka, India. The Egyptian Journal of Remote Sensing and Space Sciences 19, 125-141.

2. Cukur, H. 2014. Land degradation and natural environment in the Western Anatolia. Procedia Social and Behavioral Sciences Journal 120, 779-787.

3. Department of agriculture. 2015. Data base of food production potential. Arosuka: Agriculture Department of Solok Regency.

4. Fuseini, I. and Kemp, J. 2015. A review of spatial planning in Ghana's socio-economic developmenttrajectory: a sustainable development perspective. Land Use Policy Journal 47, 309-320.
5. George, R.M. and Kini, M.K. 2016. Formulating urban design guidelines for optimum carrying capacity of a place. Procedia Technology Journal 24, 1742-1749.

6. Gerundo, R. and Grimaldi, M. 2011. The measure of land consumption caused by urban planning. Procedia Engineering Journal 21, 1152-1160.

7. Goncalves, J. and Ferreira, J.A. 2015. The planning of strategy: a contribution to the improvement of spatial planning. Land Use Policy Journal 45, 86-94.

8. Hegazy, I.R. 2015. Integrating strategic environmental assessment into spatial planning in Egypt. Environmental Development Journal 15, 131-144.

9. Hui, C. 2015. Carrying capacity of the environment. International Encyclopedia of the Social \& Behavioral Sciences, $2^{\text {nd }}$ ed., Vol. 3, 155-160.

10. Kusumandari, A. and Nugroho, P. 2015. Land capability analysis based on hydrology and soil characteristics for watershed rehabilitation. Procedia Environmental Sciences Journal 28, 142-147.

11. Lane, M. 2010. The carrying capacity imperative : assessing regional carrying capacity methodologies for sustainable land-use planning. Land Use Policy Journal 27, 1038-1045.

12. Lee, S. and Oh, K. 2012. Environmental-ecological analysis system (EASYS) for urban planning. APCBEE Procedia Journal 1, 369-374.

13. Liu, R.Z. and Borthwick, A.G.L. 2011. Measurement and assessment of carrying capacity of the 
environment in Ningbo, China. Journal of Environmental Management 92, 2047-2053.

14. Oh, K., Jeong, Y., Lee, D., Lee, W. and Choi, J. 2005. Determining development density using the urban carrying capacity assessment system. Landscape and Urban Planning Journal 73, 1-15.

15. Rees, W. and Wackernagel, M. 1996. Urban ecological footprints: why cities cannot be sustainable and why they are a key to sustainability. New York: Elsevier Science Inc.

16. Rustiadi, E., Barus, B., Prastowo, et al. 2010. Development of Guidelines for Evaluation of Space Utilization: Completion of Regulation Attachment of Environment Ministry 17/2009 (Pengembangan Pedoman Evaluasi Pemafaatan Ruang: Penyempurnaan Lampiran Permen LH 17/2009). Jakarta: Deputi Bidang Tata Lingkungan KLH dan P4W-IPB.

17. Serrao-Neumann, S., Renouf, M., Kenway, S.J. and Choy, D.L. 2016. Connecting land-use and water planning: Prospects for an urban water metabolism approach. Cities Journal 60, 13-27.

18. Shi, Y., Wang, R., Fan, L., Li, J. and Yang, D. 2010. Analysis on Land-use change and its demographic factors in the original-stream watershed of Tarim River based on GIS and statistic. Procedia Environmental Sciences Journal 2, 175-184.

19. Soemarwoto, O. 2004. Ecology, Environment and Development (Ekologi, Lingkungan Hidup dan Pembangunan). Jakarta: Djambatan.

20. Statistic of Solok Regency (BPS). 2010. Final result calculation of population in solok regency 2010.

21. Statistic of Solok Regency (BPS). 2015. Solok regency in figure.

22. Wei, Y., Huang, C., Lam, P. T. I. and Yuan, Z. 2015. Sustainable urban development: A review on urban carrying capacity assessment. Habitat International 46, 64-71. 